\title{
GRAIN YIELD AND QUALITY OF MAIZE HYBRIDS IN DIFFERENT FAO MATURITY GROUPS
}

\author{
Has Voichita ${ }^{1}$, Radu Groza ${ }^{1}$, Ioan Has $^{2}$, Ana Copandean ${ }^{1}$, Elena Nagy ${ }^{1}$ \\ ${ }^{1}$ Agricultural Research and Development Station, Turda, Agriculturii 27, 401100 Turda, Romania \\ ${ }^{2}$ University of Agricultural Sciences and Veterinary Medicine, Cluj-Napoca, str. Mănăştur 3-5, 400372 Cluj-Napoca, Romania \\ e-mail: hasvoichita@yahoo.com; radu.groza@scdaturda.ro
}

\begin{abstract}
Summary
An improvement in the quality of maize grain by increasing the level of components responsible for its biological value is possible by using genetic means. However, a change in the genotype, together with improving the nutrient properties of the grain, also has some adverse consequences connected with a fall in yield and in resistance to diseases.

Field experiments were conducted during three years (2003, 2004and 2005) to evaluate environmental effects on grain yield and quality responses of maize hybrids. Twenty one hybrids of various maturity groups (FAO 150-400) were planted to achieve an optimum

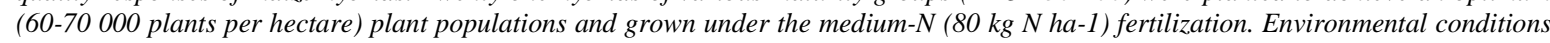
significantly affected maize hybrid responses for grain yield, starch, oil and protein contents, and consequently, starch, oil and protein yields per hectare. Hybrids of flint type, which have a short vegetation period, had high protein and oil content but the yield averages were low due to the slower rate of starch incorporation. Hybrids of the dent type have a longer growing season and more intense carbohydrate accumulation, but low protein and oil contents. In wet years there was a higher rate of starch accumulation, while dry years are favorable for protein and oil accumulation. Positive correlation existed between starch content and grain yield and 1000weight as well as between oil content and volumetric weight among tested hybrids. Negatively correlation existed between grain oil and starch content as well as between oil content and grain yield and 1000-weight. Thus, end-users that require high quality maize may need to provide incentives to growers to off set the negative correlation of grain yield with oil and protein content.

Keyword: maize, grain yield, starch content, oil and protein content
\end{abstract}

\section{INTRODUCTION}

Maize (Zea mays L) holds a significant place in the Romanian agriculture, by large area it occupy (on average $30 \%$ of arable land), the yields achieved and the multiple uses of maize grain: food for people, industry, feed. Therefore, the production and economic efficiency of maize crops are matters of national interest (Sarca et al, 2007). Using maize to get ethanol, biodegradable polymers and nutrition products led to the redirection of improvement programs to modify the content of starch, protein and oil in grains and fermentation capacity more effectively (Has et al, 2004).

The market and consumer demands led the maize improvement research study on quality characters determinism (Dudley and Lambert, 1992; Osorno and Carena, 2008; Has et al., 2009).

Improving the quality of the corn is an objective to be pursued with the same perseverance and capacity. Breeding for grain quality allows both diversification and increasing the economic value of maize cultivation. Knowledge about determinism of grain quality it is important in combination with improved grain yield and other agronomic characteristics, but also for improvement of nutritional and industrial properties (Pollak and Scott, 2005; Osorno and Carena, 2008). Increased nutritive value of maize is possible by using genetic methods and technology (Has et al, 2004; Hegyi et al, 2007; Hegyi et al, 2008; Idikut et al, 2009).

In general, attempts to improve the quality of grains are accompanied by some undesirable consequences such as reducing production capacity and resistance to diseases and pests. Therefore in the choice of maize hybrids it is necessary to be taken a balance between capacity of production and grain quality indicators (Scott et al, 2006).

Knowing that the chemical composition of grains is an important component in the characterization of each hybrid, their choice in culture is as a view for a more efficient crop (Grecu and Legman, 1994; Antohe et al, 2006; Sarca et al, 2007).

The objective of this paper is the characterization of 21 maize released hybrids about the chemical composition of grains and grain quality and the relationship between components and production parameters.

\section{MATERIAL AND METHOD OF RESEARCH}

The biological material studied consisted of 21 maize hybrids released of the following groups of materials (Official Catalogue of varieties of crop plants in Romania for 2005):

- Mid early hybrids (FAO 300-400): Saturn, Turda Super, Turda Favorit, Turda 201, Oana, Ciclon, Ileana, Neptun, Milcov, Olimp, Oituz;

- $\quad$ Early hybrids (FAO 200-300): Elan, Turda 200, Turda SU-182, Turda-Mold 188;

- Very early hybrids (FAO 100-200): Sv 108, Montana, Bucovina, Nordic, Milenium, Turda 165.

Of the 21 maize hybrids experienced, most (nine hybrids) were created at the Agricultural Research and Development Station (ARDS) Turda: Saturn, Turda Super, Turda Favorit, Turda 201, Elan, Turda 200, Turda SU-182, Turda-Mold 188, Turda 165; 6 hybrids are creations of National Agricultural Research and 
Development Institute (NARDI) Fundulea: Ciclon, Ileana, Neptun, Milcov, Olimp, Oituz; 5 hybrids are created by ARDS Suceava and a hybrid created by ARDS Podu-Iloaie.

The field trials were located at ARDS Turda in the field of maize breeding laboratory, on a cambic chernozem soil, typical for Transylvanian Plain.

Culture densities were assured for specific groups of hybrids maturity: 70,000 plants/ha (FAO 100-300), 60,000 plants/ha (FAO 300-400). Nitrogen and P fertilizer were applied at the rate of $80 \mathrm{~kg} / \mathrm{ha}$ at the sowing data. The precursory plant was winter wheat.

At each of the 21 hybrids released in the "Official Catalogue of varieties of crop plants in Romania in 2005" was studied the interaction with specific environmental conditions on the three years of experimentation at ARDS Turda of following characteristics: capacity of production, thousand of grains weight (1000-weight), volumetric weight (VW), the proportion of grains per ear, the growing season expressed as a percentage of the grain moisture at harvest, percentage of plants broken at harvest and grain composition in starch, fat and protein.

At least six plants in each experimental plot were sib-pollinated by pollen from the same plot to avoid xenia effects. Approximately five hand-pollinated ears per row were harvested, after physiological maturity, and bulked for chemical analysis, i.e. protein, fat, starch, fiber, and ash. In addition, 50 grains from the middle of each plot were removed and used for measuring moisture concentration. For each plot, a representative $50 \mathrm{~g}$ sample of the grain was ground, and the concentration of starch, protein, oil, fiber and ash in the ground (flour) sample was determined with a Dickey-John Instalab 600 near-infrared reflectance analyzer, after curve calibration.

Climatic conditions between May and September during the three years of experimentation (2003-2005) were quite different. The year 2004 was the most favorable due to a surplus of precipitation and temperature regime in June - August. Years 2003 and 2005 have been less favorable for maize crop due to the rainfall deficit during April-June and excess heat in 2003 and a rainfall surplus and heat deficit in June-August in 2005.

The data interpretation was performed by variance analysis with one factor and / or two factors (Saulescu and Saulescu, 1966), and the calculation of coefficient of variability (CV) and simple correlation coefficient (r) by Ceapoiu (1968).

\section{RESULTS AND DISCUSSION}

\section{Study of production capacity and some components of production}

Analysis of the significance (Table 1) reveals the presence of significant differences within each of the distinct characteristics studied as a result of years of experimental variability and hybrids studied.

Table 1. ANOVA for grain yield and some yield components of 21 maize hybrids in three years at ARDS Turda

\begin{tabular}{|c|c|c|c|c|c|c|c|c|c|c|c|}
\hline \multirow[t]{3}{*}{ Source } & \multirow[t]{3}{*}{$\mathrm{DF}$} & \multirow{2}{*}{\multicolumn{2}{|c|}{$\begin{array}{l}\text { Grain yield } \\
(\mathrm{U}=15.5 \%)\end{array}$}} & \multirow{2}{*}{\multicolumn{2}{|c|}{$\begin{array}{l}\text { Percentage } \\
\text { of grains /ear }\end{array}$}} & \multicolumn{2}{|c|}{$\begin{array}{l}\text { Thousand } \\
\text { of grains } \\
\text { weight }\end{array}$} & \multicolumn{2}{|c|}{$\begin{array}{l}\text { Volumetric } \\
\text { weight } \\
\text { (VW) }\end{array}$} & \multicolumn{2}{|c|}{$\begin{array}{c}\text { Grain } \\
\text { moisture at } \\
\text { harvest }\end{array}$} \\
\hline & & & & & & \multicolumn{2}{|c|}{$\mathrm{g}$} & \multicolumn{2}{|c|}{$\mathrm{kg} / \mathrm{hl}$} & \multicolumn{2}{|c|}{$\%$} \\
\hline & & s2 & & $\mathrm{s} 2$ & & s2 & & s2 & & s2 & \\
\hline Total & 62 & & & & & & & & & & \\
\hline Years & 2 & 47366926 & $* *$ & 8.68 & & 29830 & $* *$ & 469.9 & $* *$ & 433.0 & $* *$ \\
\hline Hybrids & 20 & 2157010 & $* *$ & 10.65 & $* *$ & 2158 & $* *$ & 23.6 & $* *$ & 14.3 & $* *$ \\
\hline Error & 40 & 283418 & & 4.22 & & 274.6 & & 3.7 & & 4.9 & \\
\hline
\end{tabular}

LSD 0.05 and 0.01

As a result of environmental factors fluctuation there was a large variability from one year to another, both grain yield and some components of yield (Table 2 and Fig.1).

Grain yield and some components of grain yield have been different due to the close relationship with the growing season. Hybrids with a longer growing season (for our region) (FAO 300-400) have achieved higher levels of production, compared to hybrids with a short growing season. To this group of hybrids, for achieving grain yield contributed favorable: 1000-weight, yield and a better resistance to broken at harvest, but grain moisture at harvest was higher.

Notably, the grain yield of early hybrids is close to that of the mid early hybrids, but with similarly grain moisture at harvest to extra early hybrids. With significantly higher grain yield than general mean and with a good resistance to broken, are being distinguish at harvest following hybrids: Milcov (80.8 q/ha, 1.2\%) and 
Oituz (79.4 q/ha) of group FAO 300-400 and Turda-Mold 188 (79.4 q/ha, 1.4\%) and Turda SU-182 (78.1 q / ha) of the FAO group 200-300.

Table 2. Variation of mean grain yield and for some components of production maize hybrids, experimented at ARDS Turda, 2003-2005

\begin{tabular}{|c|c|c|c|c|c|c|c|}
\hline \multirow[t]{2}{*}{ No. } & \multirow[t]{2}{*}{ Hybrid } & Grain yield & $\begin{array}{l}\text { 1000- } \\
\text { weight }\end{array}$ & VW & $\begin{array}{c}\% \text { of } \\
\text { grains/ ear }\end{array}$ & $\begin{array}{c}\text { Grain } \\
\text { moisture at } \\
\text { harvest }\end{array}$ & $\begin{array}{l}\text { Broken } \\
\text { plants at } \\
\text { harvest }\end{array}$ \\
\hline & & $\mathrm{q} / \mathrm{ha}$ & $\mathrm{g}$ & $\mathrm{kg} / \mathrm{hl}$ & $\%$ & $\%$ & $\%$ \\
\hline \multicolumn{8}{|c|}{ Mid early hybrids (FAO $300-400)$} \\
\hline 1. & Saturn & 70.2 & 327 & 69.3 & 80 & 23.9 & $\mathbf{0}$ \\
\hline 2. & Turda Super & 71.9 & 351 & 68.1 & 82 & 22.0 & 2.1 \\
\hline 3. & Turda Favorit & 75.2 & 322 & 69.2 & 79 & 24.7 & 1.9 \\
\hline 4. & Turda 201 & 73.0 & 330 & 67.9 & 81 & 22.1 & 1.0 \\
\hline 5. & Oana & 74.6 & 334 & 68.9 & 79 & 22.4 & 2.3 \\
\hline 6. & Ciclon & 58.7 & 287 & 67.6 & 80 & 19.9 & 5.2 \\
\hline 7. & Ileana & 73.9 & 293 & 66.1 & 84 & 22.2 & 2.6 \\
\hline 8. & Neptun & 76.9 & 335 & 66.6 & 82 & 23.2 & 5.0 \\
\hline 9. & Milcov & 80.8 & 351 & 65.1 & 82 & 23.1 & 1.2 \\
\hline 10. & Olimp & 77.5 & 360 & 68.1 & 79 & 24.7 & 2.0 \\
\hline 11. & Oituz & 79.4 & 323 & 67.5 & 82 & 24.1 & 3.0 \\
\hline & Mean & 73.8 & 328 & 67.7 & 80.9 & 22.9 & 2.4 \\
\hline \multicolumn{8}{|c|}{ Early hybrids (FAO $200-300)$} \\
\hline 12. & Elan & 67.8 & 308 & 72.5 & 83 & 19.8 & 6.7 \\
\hline 13. & Turda 200 & 64.9 & 331 & 67.6 & 77 & 19.8 & 9.3 \\
\hline 14. & Turda SU-182 & 78.1 & 294 & 67.8 & 81 & 19.5 & 3.0 \\
\hline 15. & Turda-Mold 188 & 79.4 & 270 & 69.4 & 79 & 18.6 & 1.4 \\
\hline & Mean & 72.6 & 301 & 69.3 & 80.0 & 19.4 & 5.1 \\
\hline \multicolumn{8}{|c|}{ Very early hybrids (FAO 100-200) } \\
\hline 16. & Sv 108 & 60.4 & 315 & 71.9 & 78 & 19.9 & 19.1 \\
\hline 17. & Montana & 51.1 & 270 & 75.3 & 77 & 18.0 & 13.9 \\
\hline 18. & Bucovina & 59.1 & 271 & 74.5 & 79 & 18.5 & 13.2 \\
\hline 19. & Nordic & 60.6 & 320 & 73.5 & 79 & 18.9 & 8.1 \\
\hline 20. & Milenium & 60.9 & 292 & 72.3 & 79 & 19.9 & 2.7 \\
\hline 21. & Turda 165 & 69.3 & 315 & 69.7 & 79 & 19.8 & 3.4 \\
\hline \multirow{2}{*}{\multicolumn{2}{|c|}{$\begin{array}{c}\text { Mean } \\
\text { General mean }\end{array}$}} & 60.2 & 297 & 71.9 & 78.5 & 19.2 & 10.1 \\
\hline & & 69.7 & 314 & 69.5 & 80.0 & 21.2 & 5.1 \\
\hline \multicolumn{2}{|c|}{ LSD 5\% } & 8.8 & 27 & 3.2 & 3 & 3.7 & 1.4 \\
\hline \multicolumn{2}{|c|}{ CV \% } & 22.3 & 13.6 & 7.2 & 3.2 & 22.0 & 66.2 \\
\hline
\end{tabular}

As shown in Table 2, the lowest mean grain yield was recorded at extra early hybrids (60.2 q / ha), but with the lowest grain moisture at harvest (19.2\%).

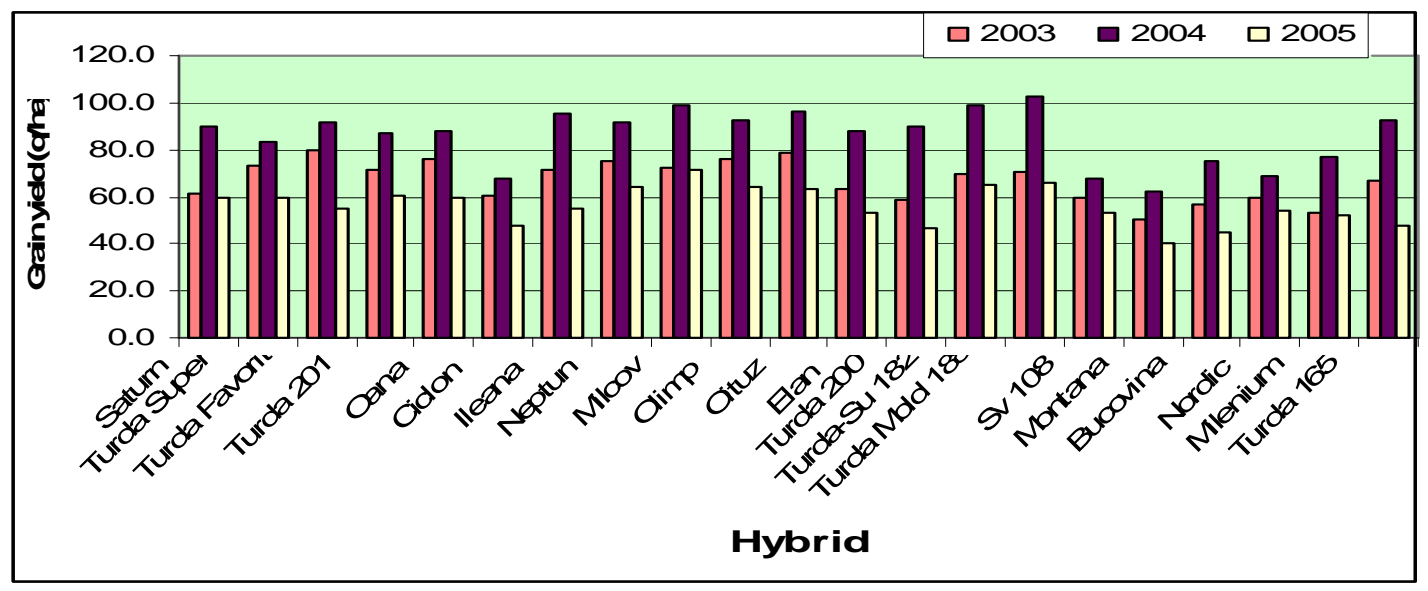

Fig. 1 - Average yield of 21 maize hybrids tested in three years at ARDS Turda 
The analysis of some components of grain yield is observed that among the 21 corn hybrids analyzed is no variability of grains on the ear $(\mathrm{CV}=3.2 \%)$, for 1000 -weight and volumetric weight (VW) variability is relatively low $(13.6 \%$ and $7.2 \%)$. Two of the hybrids were observed with a significantly higher percentage of grains/ear: Ileana $(84 \%)$ and Elan $(83 \%)$. Regarding the 1000 -weight only three hybrids is above the general mean: Olimp (360g), Turda Super (351g) and Milcov (351g). Although volumetric weight presents a low variability $(\mathrm{CV}=7.2 \%)$, four hybrids are characterized by significantly higher values than mean: Montana $(75.3 \mathrm{~kg} / \mathrm{hl})$, Bucovina $(74.5 \mathrm{~kg} / \mathrm{hl})$, Nordic $(73.5 \mathrm{~kg} / \mathrm{hl})$ and Elan $(72.5 \mathrm{~kg} / \mathrm{hl})$. Notice that all four hybrids with dent type of the grain were characterized by higher volumetric weight (VW).

Hybrids Milcov was noted for more favorable characters as: grain yield (80.8 q / ha), 1000-weight (351g), percentage of grain/ear $(82 \%)$ and plant resistance to broken $(1.2 \%)$, the hybrid was also noted in the paper published by SARCA et al. (2007). Among the early hybrids, the hybrid Turda Mold-188 hold several characters favorable: high grain yield $(79.4 \mathrm{q} / \mathrm{ha})$, low grain moisture at harvest $(18.6 \%)$ and good resistance of plants to broken $(1.4 \%)$.

\section{Study of grain content in: starch, fat and protein}

Analysis of variance significance (Table 3) reveals the presence of significant or distinct differences in each of the components of the grain content as a result of experimental years and/or hybrids studied variability, except for differences between hybrids in the protein content of grain.

Table 3. ANOVA for grain quality components of 21 maize hybrids in three years at ARDS Turda

\begin{tabular}{|l|r|r|r|r|r|r|r|}
\hline \multirow{2}{*}{ Source } & \multirow{2}{*}{ DF } & \multicolumn{2}{|c|}{ Starch } & \multicolumn{2}{|c|}{ Fat } & \multicolumn{2}{c|}{ Protein } \\
\cline { 3 - 8 } & & \multicolumn{2}{|c|}{$\%$} & \multicolumn{2}{|c|}{$\%$} & \multicolumn{2}{c|}{ Semnif. } \\
\cline { 3 - 8 } & 62 & $\mathrm{~s}^{2}$ & Semnif. & $\mathrm{s}^{2}$ & Semnif. & $\mathrm{s}^{2}$ & \\
\hline Total & 2 & 6.55 & $*$ & & & & \\
\hline Years & 20 & 4.41 & $* *$ & 0.73 & $* *$ & 0.69 & \\
\hline Hybrids & 40 & 1.65 & & 0.10 & & 0.70 & \\
\hline Error & & & & & & \\
\hline
\end{tabular}

LSD 0.05 and 0.01

Year 2004 was characterized by a rainfall and temperature surplus during the growing season, favorable conditions for accumulation of starch grains (Table 4). The rainfall deficit and excess heat in 2003, represent favourable condition for high grain protein and fat content, as emphasized by other authors: SLUSANSCHI (1957), GRECU and LEGMAN (1994), HEGYI et al. (2008).

Table 4. The variation of grain content in: starch, fat and protein of 21 maize hybrids in three years at ARDS Turda

\begin{tabular}{|c|c|c|c|c|c|}
\hline \multirow[t]{3}{*}{ No. } & \multirow{3}{*}{ Hybrid } & \multirow{3}{*}{ Grain type } & \multicolumn{3}{|c|}{ The grains composition: } \\
\hline & & & starch & fat & protein \\
\hline & & & \multicolumn{3}{|c|}{$\%$} \\
\hline 0 & 1 & 2 & 3 & 4 & 5 \\
\hline \multicolumn{6}{|c|}{ Mid early hybrids (FAO $300-400)$} \\
\hline 1. & Saturn & Dentat & 66.6 & 4.2 & 12.7 \\
\hline 2. & Turda Super & Dentat & 69.2 & 3.9 & 12.2 \\
\hline 3. & Turda Favorit & Dentat & 70.1 & 4.0 & 12.3 \\
\hline 4. & Turda 201 & Dentat & 68.8 & 4.2 & 12.7 \\
\hline 5. & Oana & Indurat & 67.4 & 4.6 & 11.7 \\
\hline 6. & Ciclon & Dentat & 67.9 & 4.1 & 12.6 \\
\hline 7. & Ileana & Dentat & 69.8 & 3.8 & 12.1 \\
\hline 8. & Neptun & Dentat & 68.9 & 3.8 & 12.5 \\
\hline 9. & Milcov & Dentat & 69.8 & 3.7 & 12.5 \\
\hline 10. & Olimp & Semiindurat & 70.1 & 3.7 & 12.5 \\
\hline 11. & Oituz & Dentat & 69.9 & 3.7 & 12.4 \\
\hline \multicolumn{3}{|c|}{ Mean } & 69.0 & 4.0 & 12.4 \\
\hline \multicolumn{6}{|c|}{ Early Hybrids (FAO $200-300)$} \\
\hline 12. & Elan & Semi-dentat & 68.9 & 4.0 & 12.0 \\
\hline 13. & Turda 200 & Dentat & 66.7 & 4.6 & 12.3 \\
\hline 14. & Turda SU-182 & Dentat & 69.9 & 4.1 & 11.6 \\
\hline 15. & Turda-Mold 188 & Dentat & 69.4 & 4.5 & 11.5 \\
\hline \multicolumn{3}{|c|}{ Mean } & 68.7 & 4.3 & 11.9 \\
\hline
\end{tabular}




\begin{tabular}{|c|c|c|c|c|c|}
\hline 0 & 1 & 2 & 3 & 4 & 5 \\
\hline \multicolumn{6}{|c|}{ Very early hybrids (FAO 100-200) } \\
\hline 16. & Sv 108 & Indurat & 68.5 & 4.2 & 11.8 \\
\hline 17. & Montana & Indurat & 68.3 & 4.7 & 11.0 \\
\hline 18. & Bucovina & Indurat & 67.8 & 4.2 & 12.8 \\
\hline 19. & Nordic & Indurat & 67.1 & 4.4 & 12.1 \\
\hline 20. & Milenium & Indurat & 66.5 & 4.7 & 12.5 \\
\hline 21. & Turda 165 & Dentat & 69.3 & 4.3 & 11.5 \\
\hline \multicolumn{3}{|c|}{ Mean } & 67.9 & 4.4 & 12.0 \\
\hline \multicolumn{6}{|c|}{ Mean /years } \\
\hline \multicolumn{3}{|c|}{2003} & 68.3 & 4.4 & 12.6 \\
\hline \multicolumn{3}{|c|}{2004} & 69.3 & 3.7 & 12.0 \\
\hline \multicolumn{3}{|c|}{2005} & 68.3 & 4.4 & 11.9 \\
\hline \multicolumn{3}{|c|}{ General mean } & 68.6 & 4.2 & 12.2 \\
\hline \multicolumn{3}{|c|}{ LSD 5\% } & 2.1 & 0.1 & 1.4 \\
\hline & & & 2.4 & 12.9 & 7.2 \\
\hline
\end{tabular}

In relation with the growing season, the increased tendency of the mean content of starch and a decreased tendency of fat content in the later hybrids $(+1.1 \%$ starch) (respectively $-0.4 \%$ fat) to very early hybrids, similar results were observed by Sarca et al. (2007), Hegyi et al. (2008).

Starch content (Table 4) showed amplitudes between $66.5 \%$ at Milenium and $70.1 \%$ at Turda Favorit and Olimp. Among the three groups of hybrids the highest starch content was performed in six of the 11 mid early hybrids: Turda Favorit (70.1\%), Olimp (70.1\%), Oituz (69.9\%), Ileana (69.8\%), Milcov (69.8\%), Turda Super $(69.2 \%)$. Among the early hybrids are distinguished by the starch grain content over $69.0 \%$ the following hybrids: Turda SU-182 (69.9\%) and Turda-Mold 188 (69.4\%) and only one very early hybrid Turda 165 $(69.3 \%)$, the starch content exceeds the hybrids group mean.

Variability (CV\%) in starch grain content is considered to be very low of $2.4 \%$. Most of the early hybrids were created based on germplasm from flint convariety and are characterized by a grain yield with a low content in starch and higher in protein and fat.

Fat grain content (Table 4) presented a mid variability $(\mathrm{CV}=12.9 \%)$. Amplitude of fat percentage was reduced for the 21 hybrids studied, between $3.7 \%$ and $4.7 \%$. The following hybrids were noted by higher oil grain content, above mean: Montana (4.7\%), Milenium (4.7\%), Oana (4.6\%), Turda 200 (4.6\%), Turda-Mold $188(4.5 \%)$. The hybrid Turda 200 should be noted that is the only hybrid with dent type of grain and a high quantity of fat and protein and low in starch.

The content in protein (Table 4) had relatively low values, amplitude ranging between $11.0 \%$ at Montana hybrid and $12.8 \%$ at Bucovina hybrid. Mid early hybrids are noted the highest values of protein grain content (12.4\%) compared with percentages recorded at early hybrids $11.9 \%$ and $12.0 \%$ at very early hybrids. The protein grain content variability was medium, determining the value of $\mathrm{CV}=7.2 \%$.

\section{The study of correlations between grain yield and quality grain content}

Relations between grain yield, components and quality of grain yield are presented in Table 5. Between chemical composition and grain yield components are statistically significant relationships.

Table 5. Simple correlation coefficients among the grain yield, yield components and grain quality traits of maize hybrids $(\mathrm{n}=63)$

\begin{tabular}{|l|r|r|r|r|r|r|}
\hline & $\begin{array}{c}\text { Starch } \\
\%\end{array}$ & $\begin{array}{c}\text { Fat } \\
\%\end{array}$ & $\begin{array}{r}\text { Protein } \\
\%\end{array}$ & $\begin{array}{r}\text { Grain yield } \\
\mathrm{q} / \mathrm{h}\end{array}$ & $\begin{array}{r}1000-\text { weight } \\
\mathrm{g}\end{array}$ & $\begin{array}{r}\mathrm{VW} \\
\mathrm{kg} / \mathrm{hl}\end{array}$ \\
\hline Starch \% & 1.00 & & & & & \\
\hline Fat \% & $-0.56^{* * *}$ & 1.00 & & & & \\
\hline Protein \% & $-0.50^{* * *}$ & -0.04 & 1.00 & & & \\
\hline Grain yield q/ha & $0.49 * * *$ & $-0.64 * * *$ & -0.03 & 1.00 & & \\
\hline 1000 -weight g & $0.30^{* *}$ & $-0.65 * * *$ & -0.03 & $0.63 * * *$ & 1.00 & \\
\hline (VW) kg/hl & $-0.26^{* *}$ & $0.42^{* * *}$ & 0.12 & $-0.27 *$ & $-0.57 * * *$ & 1.00 \\
\hline Grain moisture \% & $0.34 * *$ & $-0.58^{* * *}$ & -0.11 & $0.36 * *$ & $0.71 * * *$ & $-0.81^{* * * *}$ \\
\hline
\end{tabular}

$*_{\mathrm{r}}-\mathrm{P} 5 \%=0.25 ; \quad$ P $1 \%=0.33 ; \quad$ P0.1\% $=0.41$

In the case of the 21 hybrids analyzed are significant correlations between the following characters:

- Starch content is significantly positively correlated with grain yield $(0.49 * * *), 1000$-weight $\left(0.30^{* *}\right)$ and grain moisture at harvest $(0.34 * *)$; 
- Grain content in fat is positively correlated with volumetric weight (VW) (0.42***);

- Emphasize the existence of significant negatively correlation between fat content and grain yield $(-0.64 * * *)$, and between 1000 -weight $(-0.65 * * *)$ and grain moisture $(-0.58 * * *)$.

- Starch grain content is negatively correlated with the oil grain content $\left(-0.56^{* * *}\right)$ and protein ($0.50 * * *)$, and also with the volumetric weight $(-0.26 * *)$; similarly results were obtained by Fabijanac et al. (2006), Hegyi et al. (2008), Idikut et al. (2009).

It can be concluded, based on experimental data, that the choice of find some maize genotypes with high grain yield and all quality grain content with higher values is very difficult; therefore it is recommended to choose genotypes that simultaneously achieve a high grain yield with one of quality grain content at higher level.

\section{CONCLUSIONS}

Genotypes (hybrids) studied and years of experimentation determined variability in chemical grain composition.

Hybrids with flint grain type presented a shorter growing season and a high content in fat and protein, but grain yield has been significantly reduced due to a low rate of carbohydrates (starch) accumulation.

Hybrids with dent grain type showed generally a longer growing season and an intense accumulation of starch, but fat and protein content in grain was low.

Between the starch grain content and grain yield was a positive correlation. Between fat and protein content and grain yield was a negative correlation.

\section{RECOMMENDATIONS}

For selection of genotypes with a higher starch production it's necessary to combine some components of grain yield (grain yield, 1000-weight, percentage of grains/ear).

It is difficult to create maize hybrids with high grain yield and high fat grain content, because it's needed to be broken some negative correlations between fat grain content and grain yield, and 1000-weight, and yield.

Characterization of maize hybrids for their grains content in: starch, fat and protein, should be carried out after testing them in different environmental conditions (years, locations).

\section{REFERENCES}

Antohe, I., Cosmin, O., Sarca, TR., Dicu, G., Naidin, C., Naescu, V. (2006) High yielding, drought resistant maize hybrids with good quality traits. AN. INCDA Fundulea, LXXIV.

Ceapoiu, N. (1968) Metode statistice aplicate în experiențele agricole şi biologice. Ed. Agro-Silvică, Bucureşti.

Dudley, J.W., Lambert, R.J. (1992) Ninety generations of selection for oil land protein in maize. Maydica 37:81-87.

Fabijanac, D., Varga, B., Svečnjak, Z., Grbeša, D. (2006) Grain yield and quality of semiflint maize hybrids at two sowing dates. Agriculturae Conspectus Scientificus, vol. 71 (2): 45-50.

Grecu, C., Legman, V. (1994) Continutul şi productia de proteina, grasime si amidon a boabelor unor hibrizi si soiuri de porumb experimentati la Turda in anii 1987-1991 (Grain yield and content in protein, oil and starch of several maize hybrids and varieties experienced in the years 1987-1991 Turda). Contrib. ale cercetării ştiințifice la dezvoltarea agriculturii, vol. V: $127-141$.

Has, I., Has, V., Cabulea, I., Grecu, C., Copandean Ana, Calborean Carmen, Legman, V. (2004) Ameliorarea porumbului pentru utilizări speciale (Maize breeding for special uses). Probl. genet. teor. aplic., XXXVI, 1-2.

Has V., Has, I., Pamfil, D., Copandean, A., Campean, S. (2009) Evaluation of "TURDA" maize germplasm for phenotypic variability in grain chemical composition. Maydica 54: 313-320.

Hegyi, Z., Pók, I., Szőke, C., Pintér, J. (2007) Chemical quality parameters of maize hybrids in various FAO maturity groups as correlated with yield and yield components. Acta Agron. Hung., 55, 217-225.

Hegyi, Z., Pók, I., Berzy, T., Pintér, J., Marton, L. C. (2008) Comparison of the grain yield and quality potential of maize hybrids in different FAO maturity groups. Acta Agron. Hung., 56, 161-167.

Idikut, L., Atalay, A.I., Kara, S.N., Kamalak, A. (2009) Effect of hybrid on starch, protein and yields of maize grain. Journal of Animal and Veterinary Advances 8 (10): 1945-1947. ISSN: 1680-5593.

Osorno, J. M., Carena, M.J. (2008) Creating groups of maize genetic diversity for grain quality: implications for breeding. Maydica 53: $131-141$

Pollak, L.M., Scott, M.P. (2005) Breeding for grain quality traits. Maydica 50: 247-257.

Sarca, TR., Cosmin, O., Antohe, I. (2007) Cercetari si realizari in ameliorarea porumbului la Fundulea (Research and achievements in maize breeding at Fundulea). AN. INCDA Fundulea, LXXV, 2007, VOLUM JUBILIAR, p. 99-135.

Saulescu, N.A., Saulescu, N.N. (1967) Campul de experienta (The experimental field). Ed. Agro-Silvică, București.

Scott, M.P., Edwards, J.W., Bell, C.P., Schussler, J.R., Smith, J.S. (2006) Grain composition and amino acid content in maize hybrids representing 80 years of commercial maize varieties. Maydica. 51:417-423.

Slusanschi, H., 1957. Compoziția chimică şi întrebuințarea porumbului (Maize chemical content and uses). Porumbul - Studiu monographic (Maize - Monographic study). Ed. Acad. R.P.R., p. 138-180.

*** Catalogul oficial al soiurilor de plante de cultură din România pentru anul 2005 